Интернет-журнал «Науковедение» ISSN 2223-5167 http://naukovedenie.ru/

Выпуск 6 (25) 2014 ноябрь - декабрь http://naukovedenie.ru/index.php?p=issue-6-14

URL статьи: http://naukovedenie.ru/PDF/187EVN614.pdf

DOI: 10.15862/187EVN614 (http://dx.doi.org/10.15862/187EVN614)

УДК 311.31, 330.15, 332.3

Кривичев Александр Иванович

ФГОУ ВПО «Московский государственный университет имени М.В.Ломоносова» Лаборатория экономических проблем природопользования, экономический факультет

Россия, Москва ${ }^{1}$

Научный сотрудник

Кандидат экономических наук

E-mail: krivichev@live.ru

\title{
Максимов Юрий Игоревич
}

Музей Землеведения МГУ

Россия, Москва

Старший научный сотрудник Кандидат экономических наук E-mail: deforestation75@mail.ru

\section{Сидоренко Владимир Николаевич}

ФГОУ ВПО «Московский государственный университет имени М.В.Ломоносова» Кафедра экономики природопользования, экономический факультет

Россия, Москва

Доцент, кандидат экономических наук Кандидат физико-математических наук, кандидат юридических наук E-mail: v_sidorenko@mail.ru

\section{Земельные переписи в Российской Империи (на примере северных губерний)}

${ }^{1}$ 119234, г. Москва, Главное здание МГУ им. М.В.Ломоносова, улица Ленинские Горы, 1, 24-32 этаж. 8 (495) 939-12-21 
Аннотация. Земельные переписи, проводимые в Российской Империи с 1877 по 1905 гг., представляют серьёзный интерес для экономистов и статистиков, поскольку являются самым надёжным и достоверным источником информации о площади земель в стране, их распределении по видам земельных угодий и формам землевладения, а также позволяют сравнивать состояние землепользования в Российской Империи и в современной России.

В статье рассмотрены вопросы статистики земельных ресурсов в дореволюционной России на примере северных губерний. Подробно исследованы отдельные вопросы, в том числе связанные с изменением методологии статистического учета, дана динамика отдельных статистических показателей по Европейской России в целом и по Архангельской, Вологодской губерниям в частности.

Кроме того, рассмотрены проблемы, связанные с определением структуры земель по категории собственности в прошлом (Российской Империи) и настоящем (Российской Федерации) которые остаются актуальными, поскольку вопрос об эффективном использовании земли в России до сих пор остается открытым.

Также в статье проведено исследование структуры собственности земельных ресурсов в дореволюционной России на примере северных губерний конца XIX - начала XX века и сравнение этой структуры с современной структурой собственности соответствующих северных территорий современной России.

Ключевые слова: статистическое наблюдение; статистические учреждения; земельные ресурсы; учет земель; исторический анализ; земельные переписи; северные губернии; структура собственности; виды угодий.

\section{Ссылка для цитирования этой статьи:}

Кривичев А.И., Максимов Ю.И., Сидоренко В.Н. Земельные переписи в Российской Империи (на примере северных губерний) // Интернет-журнал «НАУКОВЕДЕНИЕ» 2014. № 6

http://naukovedenie.ru/PDF/187EVN614.pdf (доступ свободный). Загл. с экрана. Яз. рус., англ. DOI: 10.15862/187EVN614 
Одной из самых сложных проблем, стоящих на повестке сегодняшнего дня, в экономике является проблема определения земель по категории собственности. В новом законе «О внесении изменений в Земельный кодекс Российской Федерации и отдельные законодательные акты Российской Федерации» (№ 171-Ф3 "от 23.06.2014 - начнет действовать с 1 марта 2015 г.), предусмотрен ряд положений, позволяющих гражданам России более эффективно управлять своей земельной собственностью - продавать, сдавать в аренду, закладывать и передавать в залог свою недвижимость. По данным Росреестра, по состоянию на 1 января 2013 г. в государственной и муниципальной собственности находилось 92,2\% земель Российской Федерации, в собственности граждан $-6,9 \%$, в собственности юридических лиц $0,9 \%$

В частности, по данным Росреестра, на 1 января 2013 г. из общей площади земель Архангельской области, которая составляла 41 310,3 тыс. га, в государственной и муниципальной собственности находилось 40819,7 тыс. га (98,8\%), в собственности граждан 450,3 тыс. га $(1,1 \%)$, а в собственности юридических лиц $-40,3$ тыс. га $(0,1 \%)$.

Аналогично для Вологодской области, по данным Росреестра: общая площадь земель 14452,7 тыс. га, в том числе в государственной и муниципальной собственности 13 503,9 тыс. га $(93,4 \%)$, в собственности граждан - 830,3 тыс. га $(5,8 \%)$, в собственности юридических лиц 118,5 тыс. га $(0,8 \%)$.

Такая структура собственности во многом была унаследована со времен СССР и не способствовала обороту земель.

Целью данной статьи является анализ основных показателей статистики земельных ресурсов Российской Империи конца XIX - начала XX вв. на основе поземельных переписей для уточнения существовавшей структуры собственности и её сравнения с современной структурой собственности.

Исходя из этого, были поставлены следующие задачи:

- $\quad$ рассмотреть историю возникновения и развития официальных статистических учреждений в России;

- $\quad$ проанализировать сложившуюся в Российской Империи к концу XIX - началу $\mathrm{XX}$ вв. систему учёта земель;

- $\quad$ провести сравнительный анализ организации, проведения и итогов четырёх поземельных переписей Российской Империи в 1877-1878, 1881, 1887 и 1905 гг.;

- $\quad$ изучить структуру земель по формам собственности и основным видам угодий, полученную по результатам поземельных переписей.

Обратимся к статистике земельных ресурсов дореволюционной России. Первые упоминания об учёте земель появились в IX - XI веках, а первые переписи земель с характеристикой их количества и качества относятся к XII веку [9, с. 65]. Однако в ряде современных научных статей отмечается, что более-менее сопоставимая информация по отдельным показателям, характеризующим земельные ресурсы в целом по России и её регионам, имеется с начала - середины XIX в. [3, с. 40].

Появление этой информации, безусловно, связано с деятельностью статистических учреждений в Российской Империи, возникших в начале XIX века. В 1811 г. было учреждено Статистическое отделение при Министерстве полиции (с 1819 г. при Министерстве внутренних дел - МВД). [8, с. 14]. В 1834 г. были образованы губернские статистические комитеты. Статистическое отделение при МВД с 1852 г. стало называться Статистический комитет, а с 1858 г. - Центральный статистический комитет (ЦСК). 
К концу XIX в. России сложилось несколько видов учёта земель:

1) учёт, непосредственно подчинённый ЦСК МВД;

2) учёт, проводившийся другими министерствами и ведомствами;

3) учёт, который осуществляли земские статистические бюро.

Земельные переписи, проведённые ЦСК МВД в конце XIX - начале XX вв., оказались наиболее массовыми как по программе статистического наблюдения, так и по степени охвата территории. Но эти переписи ещё не являлись всероссийскими, поскольку были собраны данные только по губерниям Европейской части России. Особенностью того периода является доминирующая площадь территорий северных губерний. Самой крупной по площади была Архангельская губерния, а второй Вологодская.

Архангельская губерния занимала северную часть Европейской России и почти всё европейское прибрежье Северного Ледовитого океана, от границ шведской Лапландии до пределов Сибири и заключала в своих пределах Белое море, а также острова Вайгач и Новая Земля (площадь территории - 80771960 десятин) [2, с. 136].

Вологодская губерния, по данным генерального межевания, занимала площадь 35327372 десятины. Восточную границу губернии составлял Уральский хребет (это часть Северного Урала между 62 и $65^{\circ}$ северной широты) [2, с. 523].

Приведенные в предыдущих двух абзацах данные взяты из «Географо-статистического словаря» (том 1, 1863 г.) П.П. Семёнова Тян-Шанского (1827-1914), который был не только выдающимся путешественником и разносторонним учёным, но и крупнейшим организатором отечественной статистики. С 1864 по 1882 гг. П.П. Семёнов (фамилию Тян-Шанский он стал носить с 1906 г. как память о своих широко известных научному сообществу исследованиях на Тянь-Шане в 1856-1857 гг.) был директором ЦСК МВД [3, с. 40], [1, с. 75].

В конце 1850-х гг. П.П. Семёнов в качестве члена-эксперта и управляющего делами принимал участие в работе Редакционных комиссий, которые готовили отмену крепостного права. Он занимался обработкой необходимых для подготовки данного законопроекта статистических данных о состоянии сельского хозяйства в российских губерниях [1, с. 75].

До освобождения крестьян от крепостной зависимости, по данным, собранным известным русским статистиком Ю.Э. Янсоном (1835-1893), землевладение в Европейской России распределялось следующим образом: казна - 221 млн. десятин, помещики - 105 млн. десятин, крестьяне на правах личной собственности - 3,7 млн. десятин, колонисты $-2,5$ млн. десятин, уделы - 11,4 млн. десятин [6, с. 2]. Таким образом, казённые земли составляли 64,3\%, помещичьи земли - 30,6\%, удельные - 3,3\%, земли мелких собственников - $1,8 \%$ рассматриваемой территории.

Манифест 19 февраля 1861 года об отмене крепостного права создал в России многочисленный класс мелких поземельных собственников: около 23 млн. человек крепостного населения получили не только личную свободу, но, как правило, ещё и земельный надел. Затем основные положения манифеста были распространены на 29 млн. государственных, горнозаводских, удельных и других крестьян. Таким образом, 52 млн. человек или $77 \%$ населения России стали собственниками [6, с. 1].

Ю. Янсон в 1877 г. писал: «Всякий, кому приходилось заняться статистикою нашего землевладения, знает, в каком хаотическом состоянии находится статистический материал по этой части ... Недостаточность статистического материала не позволяет нам с достаточной подробностью и точностью определить размеры того переворота, который произвела реформа 1861 г. в распределении землевладения» [6, с. V]. 
Таким образом, назрела острая необходимость в проведении переписи поземельной собственности. И в 1877-1878 гг. такая перепись была впервые проведена - но, как уже было отмечено ранее, только по территории Европейской России. Проведение первой переписи поземельной собственности стало одной из крупнейших заслуг П.П. Семёнова как руководителя ЦСК МВД. Перепись дала ценнейший материал для развития статистики земельных ресурсов в России.

Всего ЦСК МВД провел четыре поземельных переписи в 1877-1878, 1881, 1887 и 1905 гг. При этом переписи 1877-1878, 1887 и 1905 гг. в научной и учебной литературе иногда называли переписями поземельной собственности, а перепись 1881 г. - переписью земельных угодий (см., например, [10, с. 397], [7, с. 220], [4, с. 6]). Однако учёт земель по угодьям проводился во всех поземельных переписях, начиная с 1881 г. (см. табл. 1).

Таблица 1

\section{Сравнительные характеристики поземельных переписей²}

\begin{tabular}{|c|c|c|c|c|}
\hline & $1877-1878$ & 1881 & 1887 & 1905 \\
\hline Задача & $\begin{array}{l}\text { Получить } \\
\text { точные данные о } \\
\text { размерах земли и } \\
\text { земельных } \\
\text { владений как по } \\
\text { формам } \\
\text { владений, так и } \\
\text { по } \\
\text { территориальны } \\
\text { м единицам } \\
\text { (губерниям, } \\
\text { уездам) }\end{array}$ & $\begin{array}{l}\text { Выявить точное } \\
\text { распределение } \\
\text { всех земель по } \\
\text { угодьям, а } \\
\text { пахотных } \\
\text { земель - по } \\
\text { посевам. }\end{array}$ & $\begin{array}{l}\text { Представить } \\
\text { сведения об } \\
\text { общей земельной } \\
\text { площади земель } \\
\text { и её } \\
\text { распределении } \\
\text { по угодьям и } \\
\text { землевладельцам. }\end{array}$ & $\begin{array}{l}\text { Собрать точные } \\
\text { современные } \\
\text { сведения о } \\
\text { распределении } \\
\text { земель по всем } \\
\text { видам угодий и } \\
\text { типам } \\
\text { землевладельцев. }\end{array}$ \\
\hline $\begin{array}{l}\text { Количество } \\
\text { губерний, по } \\
\text { которым } \\
\text { были } \\
\text { собраны и } \\
\text { опубликован } \\
\text { ы данные } \\
\text { переписи }\end{array}$ & 49 & 50 & $\begin{array}{l}56 \text { (без учёта } 10 \\
\text { Привислинских } \\
\text { губерний - 46) }\end{array}$ & 50 \\
\hline $\begin{array}{l}\text { Основные } \\
\text { формуляры } \\
\text { переписи }\end{array}$ & Опросные листы & $\begin{array}{l}\text { Опросные } \\
\text { листы }\end{array}$ & Анкеты & $\begin{array}{l}\text { Списки } \\
\text { землевладельцев }\end{array}$ \\
\hline $\begin{array}{l}\text { Разрезы } \\
\text { разработки }\end{array}$ & $\begin{array}{l}\text { По губерниям, } \\
\text { уездам }\end{array}$ & $\begin{array}{l}\text { По } \\
\text { земледельчески } \\
\text { м районам, } \\
\text { губерниям, } \\
\text { уездам }\end{array}$ & $\begin{array}{l}\text { По губерниям, } \\
\text { уез-дам }\end{array}$ & $\begin{array}{l}\text { По губерниям, } \\
\text { уездам }\end{array}$ \\
\hline Недостатки & $\begin{array}{l}\text { Не учитывалось } \\
\text { распределение } \\
\text { земель по } \\
\text { угодьям. }\end{array}$ & $\begin{array}{l}\text { Из-за } \\
\text { отсутствия } \\
\text { конкретных } \\
\text { указаний по }\end{array}$ & $\begin{array}{l}\text { Не были } \\
\text { получены } \\
\text { достоверные } \\
\text { данные о }\end{array}$ & $\begin{array}{l}\text { Отдельные } \\
\text { погрешности в } \\
\text { предоставленном } \\
\text { материале }\end{array}$ \\
\hline
\end{tabular}

2 Таблица составлена авторами. 


\begin{tabular}{|c|c|c|c|c|}
\hline & $1877-1878$ & 1881 & 1887 & 1905 \\
\hline & $\begin{array}{l}\text { В общей } \\
\text { площади земель } \\
\text { не учтены } \\
\text { неудобные земли } \\
\text { крестьянского } \\
\text { надела. }\end{array}$ & $\begin{array}{l}\text { заполнению } \\
\text { опросных } \\
\text { листов данные о } \\
\text { распределении } \\
\text { земель по } \\
\text { угодьям не } \\
\text { отличались } \\
\text { точностью. }\end{array}$ & $\begin{array}{l}\text { распределении } \\
\text { земель по } \\
\text { угодьям. Часть } \\
\text { земель осталась } \\
\text { нераспределённо } \\
\text { й по угодьям. } \\
\text { Перепись прошла } \\
\text { по значительно } \\
\text { сокращённой } \\
\text { программе. } \\
\text { Очень долгие } \\
\text { сроки разработки } \\
\text { материалов } \\
\text { переписи (5 лет) } \\
\text { и публикации её } \\
\text { итогов (8 лет). } \\
\text { Отсутствие } \\
\text { достоверных } \\
\text { данных по } 3 \\
\text { губерниям (не } \\
\text { были } \\
\text { опубликованы). } \\
\text { Не поступили } \\
\text { данные по } \\
\text { области Войска } \\
\text { Донского. }\end{array}$ & $\begin{array}{l}\text { остались } \\
\text { неисправленными } \\
\text { Сведения об } \\
\text { удельных и } \\
\text { казённых землях } \\
\text { ограничивались } \\
\text { данными об } \\
\text { урочных статьях } \\
\text { и не совпадали со } \\
\text { сведениями } \\
\text { центральных } \\
\text { учреждений, } \\
\text { ведавших этими } \\
\text { землями. } \\
\text { В площадь } \\
\text { городских земель } \\
\text { включалась лишь } \\
\text { облагаемая их } \\
\text { часть, т.е. } \\
\text { заселённые } \\
\text { (застроенные } \\
\text { земли). }\end{array}$ \\
\hline
\end{tabular}

Приведенная выше таблица составлена авторами на основе анализа статистических публикаций ЦСК МВД, а также более современных источников, например, учебных пособий [11], [7].

В ходе переписи 1877-1878 гг. было произведено подробное обследование населённых мест Российской Империи с распределением их по единицам землевладения, собраны данные по 49 губерниям Европейской части России.

В таблице 2 показана укрупнённая структура форм собственности, по данной переписи для северной части Европейской России. 
Таблица 2

Общее количество поземельной собственности по главным её категориям в 1877 г. ${ }^{3}$

\begin{tabular}{|c|c|c|c|c|c|}
\hline \multirow[t]{2}{*}{ Губернии } & \multirow[b]{2}{*}{$\begin{array}{c}\text { Общее } \\
\text { количество } \\
\text { поземельной } \\
\text { собственнос } \\
\text { ти }\end{array}$} & \multicolumn{4}{|c|}{ Из общего количества земли было } \\
\hline & & $\begin{array}{c}\text { Земли в } \\
\text { частной } \\
\text { собственнос } \\
\text { ти }\end{array}$ & $\begin{array}{c}\text { Земли в } \\
\text { собственнос } \\
\text { ти и } \\
\text { пользовании } \\
\text { крестьянских } \\
\text { общиин }\end{array}$ & $\begin{array}{c}\text { Казённ } \\
\text { вее и } \\
\text { удельны } \\
\text { е земли }\end{array}$ & $\begin{array}{l}\text { Остальн } \\
\text { ве земли }\end{array}$ \\
\hline \multicolumn{6}{|c|}{ Десятин } \\
\hline Европейская Россия ${ }^{4}$ & 391103966 & 93381170 & 131372457 & $\begin{array}{r}157777 \\
717\end{array}$ & 8572622 \\
\hline $\begin{array}{l}\text { Архангельская } \\
\text { губерния }\end{array}$ & 71883445 & 8865 & 277790 & $\begin{array}{r}71493 \\
035 \\
\end{array}$ & 103755 \\
\hline $\begin{array}{l}\text { в том числе по } \\
\text { уездам: } \\
\text { Архангельский }\end{array}$ & 2549318 & 2097 & 20770 & $\begin{array}{r}2518 \\
549 \\
\end{array}$ & 7902 \\
\hline Кемский & 17905847 & 1226 & 25582 & $\begin{array}{r}17819 \\
175\end{array}$ & 59864 \\
\hline Мезенский & 40097061 & 802 & 42536 & $\begin{array}{r}40046 \\
724\end{array}$ & 6999 \\
\hline Онежский & 2286215 & 1561 & 24871 & $\begin{array}{r}2239 \\
322 \\
\end{array}$ & 20461 \\
\hline Пинежский & 4853980 & 2047 & 17636 & $\begin{array}{r}4832 \\
001 \\
\end{array}$ & 2296 \\
\hline Холмогорский & 1919105 & 625 & 25646 & $\begin{array}{r}1890 \\
292 \\
\end{array}$ & 2542 \\
\hline Шенкурский & 2271919 & 507 & 120749 & $\begin{array}{r}2146 \\
972 \\
\end{array}$ & 3691 \\
\hline $\begin{array}{l}\text { Вологодская } \\
\text { губерния }\end{array}$ & 36568863 & 1343680 & 3618213 & $\begin{array}{r}31476 \\
705 \\
\end{array}$ & 130265 \\
\hline $\begin{array}{l}\text { в том числе по } \\
\text { уездам: } \\
\text { Вологодский }\end{array}$ & 518186 & 159602 & 277834 & 67782 & 12968 \\
\hline Вельский & 2266511 & 1256 & 365001 & $\begin{array}{r}1893 \\
962 \\
\end{array}$ & 6292 \\
\hline Грязовецкий & 474033 & 110116 & 221944 & 133585 & 8388 \\
\hline Кадниковский & 1452798 & 650165 & 449527 & 344445 & 8661 \\
\hline Никольский & 3584229 & 97011 & 726628 & $\begin{array}{r}2752 \\
467\end{array}$ & 8123 \\
\hline Сольвычегодский & 4037819 & 26628 & 282076 & $\begin{array}{r}3720 \\
342 \\
\end{array}$ & 8773 \\
\hline
\end{tabular}

\footnotetext{
${ }^{3}$ Статистический временник Российской империи. Серия III. Вып. 10. Поземельная собственность Европейской России 1877-1878 гг./ Изд. Центр. стат. ком. М-ва внутр. дел. - СПб, 1886.

${ }^{4}$ Суммарные данные по 49 губерниям Европейской России
} 


\begin{tabular}{|c|c|c|c|c|c|}
\hline \multirow[t]{2}{*}{ Губернии } & \multirow[b]{2}{*}{$\begin{array}{c}\text { Общее } \\
\text { количество } \\
\text { поземельной } \\
\text { собственнос } \\
\text { ти }\end{array}$} & \multicolumn{4}{|c|}{ Из общего количества земли было } \\
\hline & & $\begin{array}{c}\text { Землив в } \\
\text { частной } \\
\text { собственнос } \\
\text { ти }\end{array}$ & $\begin{array}{c}\text { Земли в } \\
\text { собственнос } \\
\text { ти и } \\
\text { пользовании } \\
\text { крестьянских } \\
\text { общчин }\end{array}$ & $\begin{array}{c}\text { Казённ } \\
\text { вье и } \\
\text { удельньл } \\
\text { е земли }\end{array}$ & $\begin{array}{l}\text { Остальн } \\
\text { ве земли }\end{array}$ \\
\hline Тотемский & 2192947 & 65013 & 508857 & $\begin{array}{r}1570 \\
149\end{array}$ & 48928 \\
\hline Устьсысольский & 14267855 & 129421 & 269507 & $\begin{array}{r}13856 \\
799\end{array}$ & 12128 \\
\hline Устюжский & 2167186 & 90808 & 353461 & $\begin{array}{r}1712 \\
534 \\
\end{array}$ & 10383 \\
\hline Яремский & 5607299 & 13660 & 163378 & $\begin{array}{r}5424 \\
640 \\
\end{array}$ & 5621 \\
\hline \multicolumn{6}{|c|}{ \% к общему количеству } \\
\hline Европейская Россия* & 100,0 & 23,9 & 33,6 & 40,3 & 2,2 \\
\hline $\begin{array}{l}\text { Архангельская } \\
\text { губерния }\end{array}$ & 100,0 & 0,0 & 0,4 & 99,5 & 0,1 \\
\hline $\begin{array}{l}\text { в том числе по } \\
\text { уездам: }\end{array}$ & & & & & \\
\hline $\begin{array}{l}\text { Архангельский } \\
\text { Кемский }\end{array}$ & $\begin{array}{r}100,0 \\
100 \Pi, 0\end{array}$ & $\begin{array}{l}0,1 \\
0,0\end{array}$ & $\begin{array}{l}0,8 \\
0,1\end{array}$ & $\begin{array}{l}98,8 \\
99,5\end{array}$ & $\begin{array}{l}0,3 \\
0,3\end{array}$ \\
\hline Мезенский & 100,0 & 0,0 & 0,1 & 99,9 & 0,0 \\
\hline Онежский & 100,0 & 0,1 & 1,1 & 97,9 & 0,9 \\
\hline Пинежский & 100,0 & 0,0 & 0,4 & 99,5 & 0,0 \\
\hline Холмогорский & 100,0 & 0,0 & 1,3 & 98,5 & 0,1 \\
\hline Шенкурский & 100,0 & 0,0 & 5,3 & 94,5 & 0,2 \\
\hline $\begin{array}{l}\text { Вологодская } \\
\text { губерния }\end{array}$ & 100,0 & 3,7 & 9,9 & 86,1 & 0,4 \\
\hline $\begin{array}{l}\text { в том числе по } \\
\text { уездам: } \\
\text { Вологодский }\end{array}$ & 100,0 & 30,8 & 53,6 & 13,1 & 2,5 \\
\hline Вельский & 100,0 & 0,1 & 16,1 & 83,6 & 0,3 \\
\hline Грязовецкий & 100,0 & 23,2 & 46,8 & 28,2 & 1,8 \\
\hline Кадниковский & 100,0 & 44,8 & 30,9 & 23,7 & 0,6 \\
\hline Никольский & 100,0 & 2,7 & 20,3 & 76,8 & 0,2 \\
\hline Сольвычегодский & 100,0 & 0,7 & 7,0 & 92,1 & 0,2 \\
\hline Тотемский & 100,0 & 3,0 & 23,2 & 71,6 & 2,2 \\
\hline Устьсысольский & 100,0 & 0,9 & 1,9 & 97,1 & 0,1 \\
\hline Устюжский & 100,0 & 4,2 & 16,3 & 79,0 & 0,5 \\
\hline Яремский & 100,0 & 0,2 & 2,9 & 96,7 & 0,1 \\
\hline
\end{tabular}

5 Доли рассчитаны авторами 
Программа переписи 1881 г. была значительно сложнее, чем в 1877/78 гг. Учитывалось распределение земель не только по категориям землевладения, как во время предыдущей переписи, но и по угодьям, а пахотных земель - по видам посевов. Разработка итоговых данных переписи была проведена не только по губерниям и уездам, но и по специально выделенным укрупнённым территориальным единицам - земледельческим районам. Данные переписи 1881 г. представлены в таблице 3.

Таблица 3

\section{Распределение земель Европейской России по основным видам угодий и категорий землевладения в 1881 г. $^{6}$}

\begin{tabular}{|c|c|c|c|c|c|}
\hline \multirow[b]{2}{*}{ Губернии } & \multirow[b]{2}{*}{ Угодья } & \multirow[b]{2}{*}{$\begin{array}{c}\text { Общее } \\
\text { количест } \\
\text { во земли }\end{array}$} & \multicolumn{3}{|c|}{ Из общего количества земли было } \\
\hline & & & $\begin{array}{c}\text { крестьян } \\
\text { ских } \\
\text { надельньl } \\
\text { x земель }\end{array}$ & $\begin{array}{c}\text { владельче } \\
\text { ских } \\
\text { земель }^{8}\end{array}$ & $\begin{array}{c}\text { казённых } \\
u \\
\text { удельныхх } \\
\text { земель }\end{array}$ \\
\hline \multicolumn{6}{|c|}{ Десятин } \\
\hline \multirow{5}{*}{$\begin{array}{l}\text { Европейская } \\
\text { Россия }^{9}\end{array}$} & пахотные & $\begin{array}{r}106666 \\
453\end{array}$ & $\begin{array}{r}74318 \\
310\end{array}$ & $\begin{array}{r}29656 \\
139\end{array}$ & 2692004 \\
\hline & лесные & $\begin{array}{r}157616 \\
608\end{array}$ & $\begin{array}{r}14016 \\
838\end{array}$ & $\begin{array}{r}41003 \\
321\end{array}$ & $\begin{array}{r}102596 \\
449\end{array}$ \\
\hline & $\begin{array}{l}\text { луга, выгоны и прочие } \\
\text { удобные земли }\end{array}$ & $\begin{array}{r}64806 \\
253\end{array}$ & $\begin{array}{r}36775 \\
883\end{array}$ & $\begin{array}{r}25420 \\
510\end{array}$ & 2609860 \\
\hline & $\begin{array}{l}\text { неудобные (болота, } \\
\text { дороги, пески и т.п.) }\end{array}$ & $\begin{array}{r}77807 \\
613\end{array}$ & $\begin{array}{r}13166 \\
453\end{array}$ & $\begin{array}{r}13007 \\
114\end{array}$ & $\begin{array}{r}51634 \\
046\end{array}$ \\
\hline & всего & $\begin{array}{r}406896 \\
927\end{array}$ & $\begin{array}{r}138277 \\
484\end{array}$ & $\begin{array}{r}109087 \\
084\end{array}$ & $\begin{array}{r}159532 \\
359\end{array}$ \\
\hline \multirow{5}{*}{$\begin{array}{l}\text { Архангельская } \\
\text { губерния }\end{array}$} & пахотные & 87701 & 81216 & 4840 & 1645 \\
\hline & лесные & $\begin{array}{r}32646 \\
044 \\
\end{array}$ & 25840 & 38426 & $\begin{array}{r}32581 \\
778 \\
\end{array}$ \\
\hline & $\begin{array}{l}\text { луга, выгоны и прочие } \\
\text { удобные земли }\end{array}$ & 189763 & 154211 & 25457 & 10095 \\
\hline & $\begin{array}{l}\text { неудобные (болота, } \\
\text { дороги, пески и т.п.) }\end{array}$ & $\begin{array}{r}38959 \\
690\end{array}$ & 30260 & 48344 & $\begin{array}{r}38881 \\
086\end{array}$ \\
\hline & всего & $\begin{array}{r}71883 \\
198 \\
\end{array}$ & 291527 & 117067 & $\begin{array}{r}71474 \\
604 \\
\end{array}$ \\
\hline \multirow{2}{*}{$\begin{array}{l}\text { Вологодская } \\
\text { губерния }\end{array}$} & пахотные & 829118 & 703400 & 115567 & 10151 \\
\hline & лесные & $\begin{array}{r}31557 \\
512 \\
\end{array}$ & 1402276 & 844654 & $\begin{array}{r}29310 \\
582 \\
\end{array}$ \\
\hline
\end{tabular}

6 Статистический временник Российской империи. Серия III. Вып. 4. Распределение земель по угодьям в Европейской России за 1881 год / Изд. Центр. стат. ком. М-ва внутр. дел. - СПб, 1884. - XLII, 45, 431 с.

7 К крестьянским надельным землям относятся земли, предоставленные в собственность или пользование крестьянских обществ по уставным грамотам или владенным записям, за исключением всех впоследствии ими приобретённых земель.

${ }^{8}$ К «владельческим землям» относятся все землевладения не только частных лиц всех сословий и крестьянских обществ, но и всех обществ и учреждений (церквей, монастырей, городов, частных обществ и т.п.), за исключением одних удельных и казённых земель.

${ }^{9}$ Суммарные данные по 50 губерниям Европейской России 


\begin{tabular}{|c|c|c|c|c|c|}
\hline \multirow{5}{*}{ Губернии } & \multirow[b]{2}{*}{ Угодья } & \multirow[b]{2}{*}{$\begin{array}{c}\text { Общее } \\
\text { количест } \\
\text { во земли }\end{array}$} & \multicolumn{3}{|c|}{ Из общего количества земли было } \\
\hline & & & $\begin{array}{c}\text { крестьян } \\
\text { ских } \\
\text { надельнь } \\
\text { х земель } \\
\end{array}$ & $\begin{array}{c}\text { владельче } \\
\text { ских } \\
\text { земель }\end{array}$ & $\begin{array}{c}\text { казённыхх } \\
u \\
\text { удельныхх } \\
\text { земель }\end{array}$ \\
\hline & $\begin{array}{l}\text { луга, выгоны и прочие } \\
\text { удобные земли }\end{array}$ & 1310996 & 980967 & 304722 & 25307 \\
\hline & $\begin{array}{l}\text { неудобные (болота, } \\
\text { дороги, пески и т.п.) }\end{array}$ & 2855234 & 499293 & 226980 & 2128961 \\
\hline & всего & $\begin{array}{r}36552 \\
860\end{array}$ & 3585936 & 1491923 & $\begin{array}{r}31475 \\
001\end{array}$ \\
\hline \multicolumn{6}{|c|}{ В\% к общему количеству $y^{10}$} \\
\hline \multirow{5}{*}{$\begin{array}{l}\text { Европейская } \\
\text { Россия }\end{array}$} & пахотные & 100,0 & 69,7 & 27,8 & 2,5 \\
\hline & лесные & 100,0 & 8,9 & 26,0 & 65,1 \\
\hline & $\begin{array}{l}\text { луга, выгоны и прочие } \\
\text { удобные земли }\end{array}$ & 100,0 & 56,7 & 39,2 & 4,0 \\
\hline & $\begin{array}{l}\text { неудобные (болота, } \\
\text { дороги, пески и т.п.) }\end{array}$ & 100,0 & 16,9 & 16,7 & 66,4 \\
\hline & всего & & & & \\
\hline \multirow{5}{*}{$\begin{array}{l}\text { Архангельская } \\
\text { губерния }\end{array}$} & пахотные & 100,0 & 92,6 & 5,5 & 1,9 \\
\hline & лесные & 100,0 & 0,1 & 0,1 & 99,8 \\
\hline & $\begin{array}{l}\text { луга, выгоны и прочие } \\
\text { удобные земли }\end{array}$ & 100,0 & 81,3 & 13,4 & 5,3 \\
\hline & $\begin{array}{l}\text { неудобные (болота, } \\
\text { дороги, пески и т.п.) }\end{array}$ & 100,0 & 0,1 & 0,1 & 99,8 \\
\hline & всего & 100,0 & 0,4 & 0,2 & 99,4 \\
\hline \multirow{5}{*}{$\begin{array}{l}\text { Вологодская } \\
\text { губерния }\end{array}$} & пахотные & 100,0 & 84,8 & 13,9 & 1,2 \\
\hline & лесные & 100,0 & 4,4 & 2,7 & 92,9 \\
\hline & $\begin{array}{l}\text { луга, выгоны и прочие } \\
\text { удобные земли }\end{array}$ & 100,0 & 74,8 & 23,2 & 1,9 \\
\hline & $\begin{array}{l}\text { неудобные (болота, } \\
\text { дороги, пески и т.п.) }\end{array}$ & 100,0 & 17,5 & 7,9 & 74,6 \\
\hline & всего & 100,0 & 9,8 & 4,1 & 86,1 \\
\hline
\end{tabular}

По мнению статистиков того времени, наибольшая неопределённость ощущалась в показаниях о площади под лесами, пастбищами и выгонами, не говоря о неудобных землях, сведения о которых могли быть только приблизительными. Основное затруднение заключалось в распределении пространства под выгонами и под лесной зарослью. Наиболее определёнными являются пространства пахотных и сенокосных земель.

Следующая поземельная перепись 1887 г. проводилась в форме анкетного обследования. Программа переписи 1887 г. была значительно сокращена по сравнению с первоначальным планом, в результате чего сопоставление её итогов с итогами переписи 1877 г. оказалось сильно затруднено. Материалы переписи разрабатывались около 5 лет, а публикация её итогов растянулась ещё на 8 лет. Таблица 4 иллюстрирует укрупнённую структуру форм собственности, полученную в ходе данной переписи.

${ }^{10}$ Доли рассчитаны авторами. 


\section{Таблица 4}

\section{Распределение земель Европейской России по основным видам угодий и категорий землевладения в 1887 г. $^{11}$}

\begin{tabular}{|c|c|c|c|c|c|c|}
\hline \multirow[t]{2}{*}{ Губернии } & \multirow[t]{2}{*}{ Угодья } & \multirow{2}{*}{$\begin{array}{c}\text { Общуее } \\
\text { количест } \\
\text { во земли }\end{array}$} & \multicolumn{4}{|c|}{ В том числе } \\
\hline & & & $\begin{array}{c}\text { крестьянс } \\
\text { ких } \\
\text { надельных } \\
\text { земель }\end{array}$ & $\begin{array}{c}\text { частных } \\
\text { владельчес } \\
\text { ких } \\
\text { земель }\end{array}$ & $\begin{array}{c}\text { казённыхх и } \\
\text { удельных } \\
\text { земель }\end{array}$ & $\begin{array}{l}\text { остальны } \\
\text { х земель }\end{array}$ \\
\hline \multicolumn{7}{|c|}{ Десятин } \\
\hline \multirow[t]{6}{*}{$\begin{array}{l}\text { Европейская } \\
\text { Россия }^{14}\end{array}$} & пахотные & $\begin{array}{r}109143 \\
003\end{array}$ & 71419590 & 32745034 & 2732500 & 2245879 \\
\hline & лесные & $\begin{array}{r}148748 \\
583\end{array}$ & 14721573 & 36852168 & 95132519 & 2042323 \\
\hline & $\begin{array}{l}\text { луга, выгоны и } \\
\text { прочие удобные } \\
\text { земли }\end{array}$ & $\begin{array}{r}59027 \\
628\end{array}$ & 29270492 & 16652954 & 8197711 & 4906471 \\
\hline & неудобные & $\begin{array}{r}65577 \\
610 \\
\end{array}$ & 10782492 & 9816366 & 44053698 & 925054 \\
\hline & $\begin{array}{l}\text { нераспределённы } \\
\text { е }\end{array}$ & 1618508 & 43079 & 840032 & 670708 & 64689 \\
\hline & всего & $\begin{array}{r}384238 \\
974\end{array}$ & $\begin{array}{r}126237 \\
226\end{array}$ & 97030196 & 150787136 & 10184416 \\
\hline \multirow{6}{*}{$\begin{array}{l}\text { Архангельск } \\
\text { ая губерния }\end{array}$} & пахотные & 91266 & 84267 & 410 & 2824 & 3765 \\
\hline & лесные & $\begin{array}{r}32649 \\
781 \\
\end{array}$ & 78023 & 289 & 32546632 & 24837 \\
\hline & \begin{tabular}{|lr} 
луга, выгоны и \\
прочие \\
земли
\end{tabular} & 160826 & 138562 & 787 & 9315 & 12162 \\
\hline & неудобные & $\begin{array}{r}38948 \\
393 \\
\end{array}$ & 25911 & 811 & 38883169 & 38502 \\
\hline & $\begin{array}{l}\text { нераспределённы } \\
\text { е }\end{array}$ & 27940 & 0 & 0 & 0 & 27940 \\
\hline & всего & $\begin{array}{r}71878 \\
206\end{array}$ & 326763 & 2297 & 71441940 & 107206 \\
\hline \multirow{4}{*}{$\begin{array}{l}\text { Вологодская } \\
\text { губерния }\end{array}$} & пахотные & 841686 & 735490 & 54931 & 33854 & 17411 \\
\hline & лесные & $\begin{array}{r}31333 \\
383 \\
\end{array}$ & 1202195 & 954538 & 29114054 & 62596 \\
\hline & $\begin{array}{|lr|}\text { луга, выгоны } \\
\text { прочие } \\
\text { 3емли }\end{array}$ & 2290409 & 1019152 & 217900 & 977329 & 76028 \\
\hline & неудобные & 1910798 & 478069 & 182703 & 1238985 & 11041 \\
\hline
\end{tabular}

\footnotetext{
${ }^{11}$ Статистика Российской Империи. Главнейшие данные поземельной статистики по обследованию 1887 года / Изд. Центр. стат. ком. М-ва внутр. дел. - СПб, 1892-1901

12 Наряду с частными владельческими землями в переписи 1887 г. встречаются термины «земли (в) частной собственности», «земли частных владельцев».

${ }^{13}$ К остальным землям относятся земли монастырские, церковные, городские и разных учреждений.

${ }^{14}$ Расчетные данные по 56 губерниям Европейской России (с учётом 10 Привислинских губерний)
} 


\begin{tabular}{|c|c|c|c|c|c|c|}
\hline \multirow[t]{4}{*}{ Губернии } & \multirow[t]{2}{*}{ Угодья } & \multirow{2}{*}{$\begin{array}{c}\text { Общуее } \\
\text { количест } \\
\text { во земли }\end{array}$} & \multicolumn{4}{|c|}{ В том числе } \\
\hline & & & $\begin{array}{c}\text { крестьянс } \\
\text { ких } \\
\text { надельных } \\
\text { земель }\end{array}$ & $\begin{array}{c}\text { частных } \\
\text { владельчес } \\
\text { ких } \\
\text { земель }\end{array}$ & $\begin{array}{c}\text { казённых и } \\
\text { удельныхх } \\
\text { земель }\end{array}$ & $\begin{array}{l}\text { остальны } \\
\text { х земель }\end{array}$ \\
\hline & $\begin{array}{l}\text { нераспределённы } \\
\text { е }\end{array}$ & 123642 & 0 & 123642 & 0 & 0 \\
\hline & всего & $\begin{array}{r}36499 \\
918\end{array}$ & 3434906 & 1533714 & 31364222 & 167076 \\
\hline \multicolumn{7}{|c|}{ В\% к общему количеству ${ }^{15}$} \\
\hline \multirow{6}{*}{$\begin{array}{l}\text { Европейская } \\
\text { Россия }\end{array}$} & пахотные & 100,0 & 65,4 & 30,0 & 2,5 & 2,1 \\
\hline & лесные & 100,0 & 9,9 & 24,8 & 64,0 & 1,4 \\
\hline & $\begin{array}{l}\text { луга, выгоны и } \\
\text { прочие } \text { удобные } \\
\text { земли }\end{array}$ & 100,0 & 49,6 & 28,2 & 13,9 & 8,3 \\
\hline & неудобные & 100,0 & 16,4 & 15,0 & 67,2 & 1,4 \\
\hline & $\begin{array}{l}\text { нераспределённы } \\
\text { е }\end{array}$ & 100,0 & 2,7 & 51,9 & 41,4 & 4,0 \\
\hline & всего & 100,0 & 32,9 & 25,3 & 39,2 & 2,7 \\
\hline \multirow{6}{*}{$\begin{array}{l}\text { Архангельск } \\
\text { ая губерния }\end{array}$} & пахотные & 100,0 & 92,3 & 0,4 & 3,1 & 4,1 \\
\hline & лесные & 100,0 & 0,2 & 0,0 & 99,7 & 0,1 \\
\hline & $\begin{array}{|lr|}\text { луга, выгоны и } \\
\text { прочие } \\
\text { земли }\end{array}$ & 100,0 & 86,2 & 0,5 & 5,8 & 7,6 \\
\hline & неудобные & 100,0 & 0,1 & 0,0 & 99,8 & 0,1 \\
\hline & $\begin{array}{l}\text { нераспределённы } \\
\text { е }\end{array}$ & 100,0 & 0,0 & 0,0 & 0,0 & 100,0 \\
\hline & всего & 100,0 & 0,5 & 0,0 & 99,4 & 0,1 \\
\hline \multirow{6}{*}{$\begin{array}{l}\text { Вологодская } \\
\text { губерния }\end{array}$} & пахотные & 100,0 & 87,4 & 6,5 & 4,0 & 2,1 \\
\hline & лесные & 100,0 & 3,8 & 3,0 & 92,9 & 0,2 \\
\hline & $\begin{array}{|lr|}\text { луга, выгоны и } \\
\text { прочие } \\
\text { земли }\end{array}$ & 100,0 & 44,5 & 9,5 & 42,7 & 3,3 \\
\hline & неудобные & 100,0 & 25,0 & 9,6 & 64,8 & 0,6 \\
\hline & $\begin{array}{l}\text { нераспределённы } \\
\text { е }\end{array}$ & 100,0 & 0,0 & 100,0 & 0,0 & 0,0 \\
\hline & всего & 100,0 & 9,4 & 4,2 & 85,9 & 0,5 \\
\hline
\end{tabular}

При этом владельцы земли распределялись по группам и видам. Было выделено три группы землевладельцев: 1) частные собственники; 2) общины, пользующиеся надельной землёй; 3) государство, церковь и разные учреждения и установления.

Программа переписи поземельной собственности 1905 г. в целом соответствовала программе переписи 1877 г., однако при разработке итогов переписи группировка земель по формам собственности была изменена: к землям первой группы были отнесены земли частных обществ, товариществ и компаний, которые ранее относились к третьей группе.

В таблице 5 представлены данные трёх поземельных переписей.

15 Доли рассчитаны авторами. 
Таблица 5

\section{Земельная собственность с распределением её по главным категориям в $1877,1887,1905$ гг. ${ }^{16}$}

\begin{tabular}{|c|c|c|c|c|c|}
\hline \multirow[b]{2}{*}{ Губернии } & \multirow[b]{2}{*}{ Год } & \multirow[b]{2}{*}{$\begin{array}{c}\text { Обшуее } \\
\text { количество } \\
\text { земли }\end{array}$} & \multicolumn{3}{|c|}{ Из общего количества земли было } \\
\hline & & & $\begin{array}{c}\text { земель в } \\
\text { частной } \\
\text { собственности }\end{array}$ & $\begin{array}{c}\text { надельных } \\
\text { земель }\end{array}$ & $\begin{array}{c}\text { земель } \\
\text { государства, } \\
\text { церкви и } \\
\text { учреждений }\end{array}$ \\
\hline \multicolumn{6}{|c|}{ Десятин } \\
\hline \multirow[t]{3}{*}{ Европейская Россия } & 1877 & 391103966 & 93381170 & 131372457 & 166350339 \\
\hline & 1887 & 384238974 & 97030196 & 126237226 & 160971552 \\
\hline & 1905 & 395192443 & 101735343 & 138767587 & 154689513 \\
\hline \multirow{3}{*}{$\begin{array}{l}\text { Архангельская } \\
\text { губерния }\end{array}$} & 1877 & 71883445 & 8865 & 277790 & 71596790 \\
\hline & 1887 & 71878206 & 2297 & 326763 & 71549146 \\
\hline & 1905 & 71996158 & 64121 & 334848 & 71597189 \\
\hline \multirow[t]{3}{*}{ Вологодская губерния } & 1877 & 36568863 & 1343680 & 3618213 & 31606970 \\
\hline & 1887 & 36499918 & 1533714 & 3434906 & 31531298 \\
\hline & 1905 & 34939643 & 1479924 & 3699372 & 29760347 \\
\hline \multicolumn{6}{|c|}{$\%$ к итогу $y^{17}$} \\
\hline \multirow[t]{3}{*}{ Европейская Россия } & 1877 & 100,0 & 23,9 & 33,6 & 42,5 \\
\hline & 1887 & 100,0 & 25,3 & 32,9 & 41,9 \\
\hline & 1905 & 100,0 & 25,7 & 35,1 & 39,1 \\
\hline \multirow{3}{*}{$\begin{array}{l}\text { Архангельская } \\
\text { губерния }\end{array}$} & 1877 & 100,0 & 0,0 & 0,4 & 99,6 \\
\hline & 1887 & 100,0 & 0,0 & 0,5 & 99,5 \\
\hline & 1905 & 100,0 & 0,1 & 0,5 & 99,4 \\
\hline \multirow[t]{3}{*}{ Вологодская губерния } & 1877 & 100,0 & 3,7 & 9,9 & 86,4 \\
\hline & 1887 & 100,0 & 4,2 & 9,4 & 86,4 \\
\hline & 1905 & 100,0 & 4,2 & 10,6 & 85,2 \\
\hline
\end{tabular}

Из таблицы видно, что структура собственности по данным земельных переписей с 1877 по 1905 гг. в рассматриваемых губерниях не претерпела значительных изменений, причём наиболее стабильным оказалось распределение земель по категориям собственности в Архангельской губернии, где почти все земли находились в собственности государства, церкви и учреждений. Тем не менее, и в Архангельской, и в Вологодской губерниях, и в целом по Европейской России отмечалась тенденция увеличения площади земель в частной собственности и надельных земель наряду с сокращением площади земель государства, церкви и учреждений.

Если же сравнивать данные по губерниям с данными по Европейской части России, то можно сделать вывод о том, что чем меньше плотность населения, тем меньше доля земель в частной собственности. Для сравнения приведём данные поземельной переписи 1905 г.: доля

\footnotetext{
16 Статистический временник Российской империи. Серия III. Вып. 10. Поземельная собственность Европейской России 1877-1878 гг./ Изд. Центр. стат. ком. М-ва внутр. дел. - СПб, 1886.; Статистика Российской Империи. Главнейшие данные поземельной статистики по обследованию 1887 года / Изд. Центр. стат. ком. М-ва внутр. дел. - СПб, 1892-1901; Статистика землевладения. 1905 г. Свод данных по 50 губерниям Европейской России/ Центр. стат. ком. М-ва внутр. дел. - СПб., 1907.

17 Доли рассчитаны авторами.
} 
земель в частной собственности в Санкт-Петербургской губернии составляла 54,8\%, а в Московской губернии - 36,0\% [5, с. 286].

Сравнивая дореволюционные Архангельскую и Вологодскую губернии (по данным последней поземельной дореволюционной переписи 1905 г.) с современными одноименными областями, можно заметить, что в Архангельской области доля земель в частной собственности увеличилась с 0,1 до 1,1\%, а в Вологодской - с 4,2 до 5,8\%.

Однако следует учитывать, что прямое сравнение структуры собственности в Российской Империи и современной Российской Федерации не совсем корректно по следующим причинам: 1) категории поземельной собственности в дореволюционной России сильно отличаются от современных видов федеральной собственности (см. таблицы 2-5); 2) изменения в административно-территориальном делении нашей страны: территория Вологодской губернии по площади превосходила современные территории Вологодской области почти в 3 раза, а территория Архангельской губернии превосходила современную территорию Архангельской области примерно на треть (без учета островов). 


\section{ЛИТЕРАТУРА}

1. Богданов А.А., Хижняков Б.П. П.П. Семёнов-Тян-Шанский и его роль в становлении российской статистики // Вопросы статистики, 2011, № 11. - С. 75 77.

2. Географо-статистический словарь Российской империи/ Составитель П.П Семенов. Том 1 - Тип. Безобразова и комп. - СПб., 1863. - VIII, 716 с.

3. Думнов А.Д. Статистика окружающей природной среды: генезис, предмет и задачи изучения, информационно-аналитический аппарат // Использование и охрана природных ресурсов в России, 2002, № 3. - С. 36-62.

4. Думнов А.Д. Статистика окружающей природной среды: история и современность // Вопросы статистики. 2008, № 3. - С. 5-18.

5. Максимов Ю.И., Сидоренко В.Н., Кривичев А.И. Статистика земельных ресурсов в дореволюционной России // Жизнь Земли: землеведение, экология, геодинамика, музеология. Сборник научных трудов Музея Землеведения МГУ. Вып. 35/36 /Под ред. В.А. Садовничего и А.В. Смурова. - М.: Издательство Московского университета, 2014. -С. 269-289.

6. Опыт статистического исследования о крестьянских наделах и платежах / [Соч.] Ю. Янсона, проф. С.-Петерб. ун-та. - СПб.: Тип. Стасюлевича, 1877. - VIII, 160, $26 \mathrm{c}$.

7. Проскурякова Н.В. Статистика землевладения и землепользования // В сб. «Массовые источники по социально-экономической истории России периода капитализма». - М.:, Наука - 1979. - С. 219-244.

8. Сельскохозяйственные переписи в России/ Председатель ред. коллегии Соколин В.Л. - М.: ИИЦ «Статистика России», 2007. - 304 с.

9. Сидоренко В.Н. Государственный земельный кадастр: прошлое, настоящее, будущее. - М.: ТЕИС, 2003. - 320 с.

10. Статистический словарь / Гл. ред. Ежов А.И. - М.: Статистика, 1965. - 708 с.

11. Щапина Т.А. Статистика землепользования и земельных угодий: Учебное пособие / МЭСИ. - М., 1957. - 48 с.

Рецензент: Никоноров Сергей Михайлович, в.н.с., д.э.н. кафедра экономики природопользования экономического факультета МГУ им. М.В. Ломоносова. 


\title{
Krivichev Alexandr Ivanovich \\ Moscow State University named after MV Lomonosov \\ Russia, Moscow \\ E-mail: krivichev@live.ru
}

Maksimov Yuriy Igorevich

The Earth Science Museum at Moscow State University named after MV Lomonosov

Russia, Moscow

E-mail: deforestation75@mail.ru

Sidorenko Vladimir Nikolaevich

Moscow State University named after MV Lomonosov

Russia, Moscow

E-mail: v_sidorenko@mail.ru

\section{Land census in the Russian Empire (for example, the northern provinces)}

\begin{abstract}
Land census conducted in the Russian Empire from 1877 to 1905 represent a serious concern to economists and statisticians, because they are the most reliable and credible source of information on the area of land in the country, their distribution by type of land and land tenure, as well as allow you to compare state land in the Russian Empire and in modern Russia.

The paper deals with the statistics of land resources in pre-revolutionary Russia by the example of the northern provinces. Studied in detail the individual issues, including those related to changes in the methodology of statistics, given the dynamics of individual statistical indicators of European Russia as a whole and in the Arkhangelsk, Vologda province in particular.

Besides the problems associated with determining the structure of land ownership category in the past (Russian Empire) and the present (the Russian Federation) which remain relevant, since the question of efficient use of land in Russia is still open.

Also, the article investigated the structure of land ownership in pre-revolutionary Russia by the example of the northern provinces of the late XIX - early XX century and a comparison of this structure with a modern structure of their respective northern territories of modern Russia.
\end{abstract}

Keywords: statistical observations; statistical agencies; land re-resources; including land under historical analysis; land census; the northern province; ownership structure; types of land. 


\section{REFERENCES}

1. Bogdanov A.A., Khizhnyakov B.P. P.P. Semenov-Tyan-Shanskiy i ego rol' v stanovlenii rossiyskoy statistiki // Voprosy statistiki, 2011, № 11. - S. 75-77.

2. Geografo-statisticheskiy slovar' Rossiyskoy imperii/ Sostavitel' P.P Semenov. Tom 1 Tip. Bezobrazova i komp. - SPb., 1863. - VIII, 716 s.

3. Dumnov A.D. Statistika okruzhayushchey prirodnoy sredy: genezis, predmet i zadachi izucheniya, informatsionno-analiticheskiy apparat // Ispol'zovanie i okhrana prirodnykh resursov v Rossii, 2002, № 3. - S. 36-62.

4. Dumnov A.D. Statistika okruzhayushchey prirodnoy sredy: istoriya i sovremennost' // Voprosy statistiki. 2008, № 3. - S. 5-18.

5. Maksimov Yu.I., Sidorenko V.N., Krivichev A.I. Statistika zemel'nykh resursov v dorevolyutsionnoy Rossii // Zhizn' Zemli: zemlevedenie, ekologiya, geodinamika, muzeologiya. Sbornik nauchnykh trudov Muzeya Zemlevedeniya MGU. Vyp. 35/36 /Pod red. V.A. Sadovnichego i A.V. Smurova. - M.: Izdatel'stvo Moskovskogo universiteta, 2014. -S. 269-289.

6. Opyt statisticheskogo issledovaniya o krest'yanskikh nadelakh i platezhakh / [Soch.] Yu. Yansona, prof. S.-Peterb. un-ta. - SPb.: Tip. Stasyulevicha, 1877. - VIII, 160, 26 s.

7. Proskuryakova N.V. Statistika zemlevladeniya i zemlepol'zovaniya // V sb. «Massovye istochniki po sotsial'no-ekonomicheskoy istorii Rossii perioda kapitalizma». - M.:, Nauka - 1979. - S. 219-244.

8. Sel'skokhozyaystvennye perepisi v Rossii/ Predsedatel' red. kollegii Sokolin V.L. - M.: IITs «Statistika Rossii», 2007. - 304 s.

9. Sidorenko V.N. Gosudarstvennyy zemel'nyy kadastr: proshloe, nastoyashchee, budushchee. - M.: TEIS, 2003. - $320 \mathrm{~s}$.

10. Statisticheskiy slovar' / Gl. red. Ezhov A.I. - M.: Statistika, 1965. - 708 s.

11. Shchapina T.A. Statistika zemlepol'zovaniya i zemel'nykh ugodiy: Uchebnoe posobie / MESI. - M., 1957. - 48 s. 